\title{
重イオン照射高分子膜
}

\author{
高橋周一 \\ Department of Chemical Engineering, The University of Texas at Austin \\ Austin, TX78712, USA
}

\section{Heavy-Ion Irradiated Polymer Membranes}

\author{
Shuichi Takahashi \\ Department of Chemical Engineering, The University of Texas at Austin \\ Austin, TX 78712, USA
}

\begin{abstract}
Recently, there has been growing interest in the heavy ion irradiation of polymer membranes. Heavy-ion irradiation is an interesting modification technique for various polymeric membranes and often causes different chemical effects as a result of the $\gamma$-ray or electron-beam irradiation. The poly (ethylene terephthalate) (PET) membrane was mainly used in these studies. The structure change of the heavy-ion irradiated membrane was followed using some dynamic and thermal measurements with the aim to understand the chemical change in the material after the heavy-ion irradiation. It is considered that the secondary electron is induced by the collision between the irradiated ion and the constituent atoms of the membrane material to form the cross-linking. A portion of heavy-ion irradiated PET membranes exhibited Knudsen flow in the gas permeation measurements. As a next step, the author applied an etching technique utilizing $\mathrm{NaOH}$ solution to control the nanosized pores into the heavy-ion irradiated PET membrane. The etching time was controlled in order to observe the change in the gas permeation behavior depending on the etching. The effect of heavy-ion irradiation on the hydrophilic copolymer with bulky hydrophobic pendant was also attempted for application as contact lenses. The dissolved oxygen permeability of the heavy-ion irradiated copolymer membranes became higher compared to that of the untreated membranes.
\end{abstract}

Key words : heavy-ion irradiation / poly (ethylene terephthalate) / cross-linking / Knudsen flow / permeability

\section{1.はじめに}

高分子膜は，幅広い分野で使用されており，その 用途別に材料が選択され，モルホロジーも目的・贸 求に適した材料へと改犋される，特に膜による分離 機能は，工業的にも広く応用されており，各々の膜

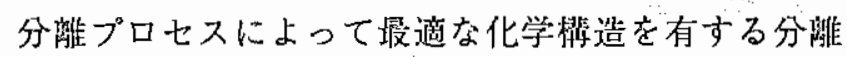
膜が開発されている，一般的に，膜は多孔膜と非多 孔膜に分頪され，用途によってその分灕ブロセスと 分嚄機權も分類される。孔径が $10 \mathrm{~A}$ 以下での孔は物 理的に固定されれレべルではなく，膜を㭗成する高 分子鎖通動において生じる孔として判断される。こ のような高分子膜を非多孔膜といい，非多孔膜にお ける分㫿機能は，この孔形成のしやすさが重要な因 子となっている。このような膜を目的に応じた “漫
適”な材料として応用するには，少なからず改質が 必要であり，その改質方法も多種多様である。

本説で諭述する改質方法は离エネルギー人工放射 線である重イオンを用いたものであり，高分子膜の 重イオン照射改啠とその膜满造変化に闑する現象を, 低分子透過性を中心に紹介する。

\section{2. 重イオン照射}

重イオン照射は, 日本原子力研究所高崎研究所 AVFサイクロトロン（TIARA）に接続されたFig. 1に

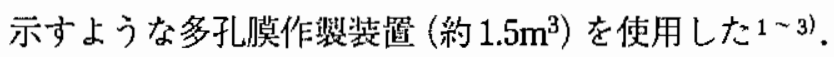
サイクロトロンから輸送されたイオンビームは散乱 板を介して膜に照射される。ガラス板でサポートさ れた $5 \mathrm{~cm}^{2}$ の膜はFig. 1，Chamber内の回転式セル 


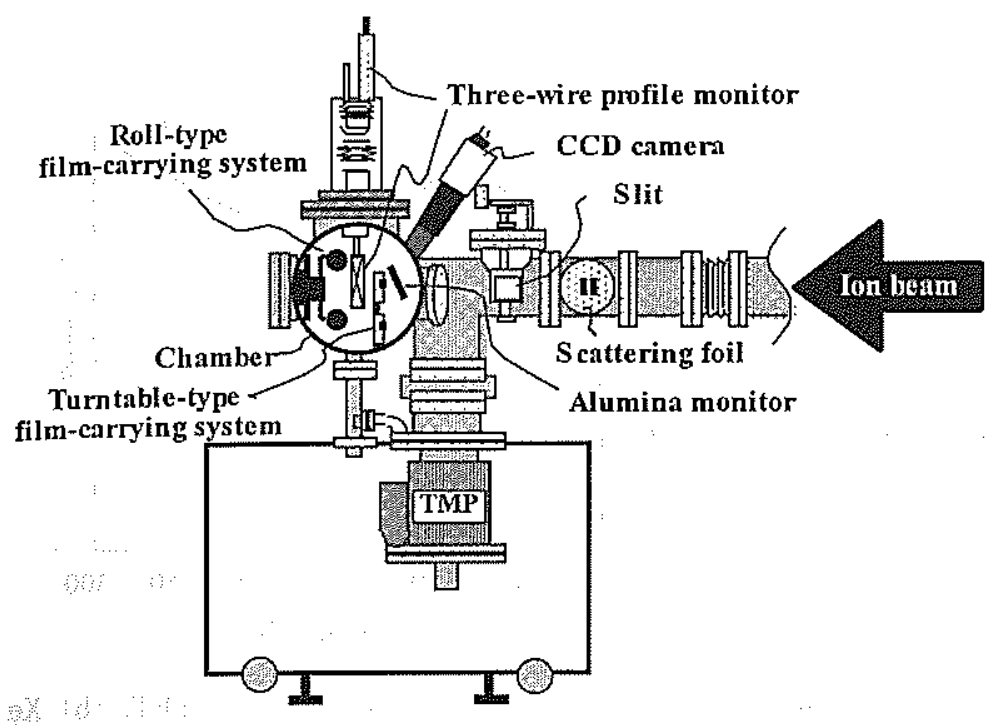

Fig. 1 Schematic representation of the chamber connected with the AVF cyclotron in the Takasaki ion accelerators for advanced radiation applications (TIARA). TMP is short for Temperature controller.

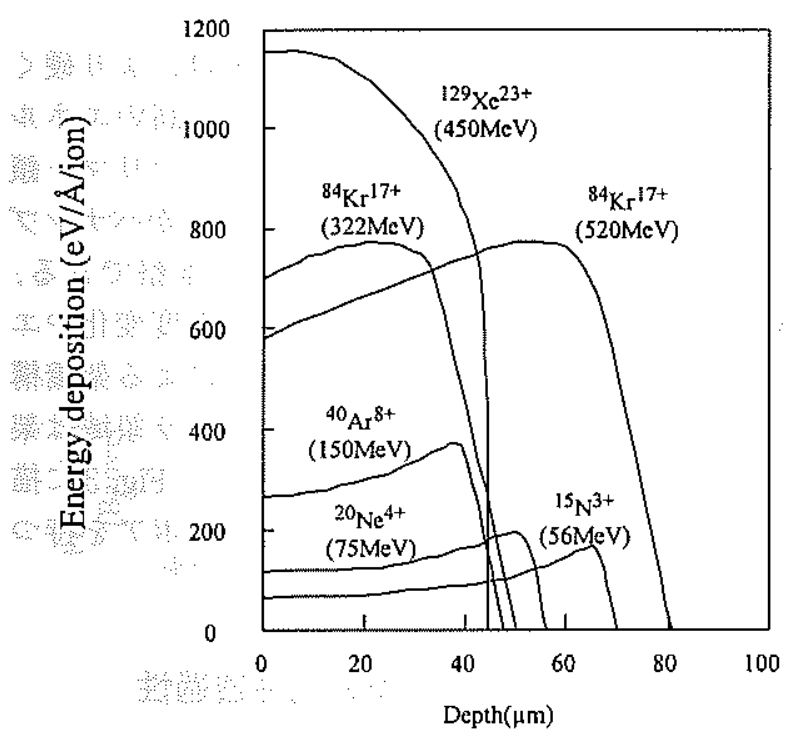

Fig. 2 . Bragg curve of various ions for a diethyleneglycolbis-allylcarbonate film calculated according to the TRIM-code program.

(Turntable-type film-carrying system)に合計 6 枚まで セットされ，セルを回転させて順次重イオンを照射 させることが出来る。照射雲囲気は真空状態に保た れる。またたオンビームの照射面穔はコントロール 仃能であり；照射ビームの分布形状は図中のアルミ ナモニターとCCDカメラを用いることによりブラウ ン管止で碓認できる。ささらに照射ビームの分布は多

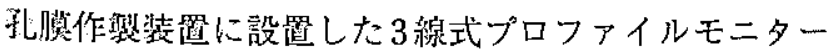
を用りてビーム操作側でも確認できる。単位面䅡あ たりの照射イオンビーム数（フルエンス）は（1）式 に示したようにイオンの佂数 $(N)$ と電流值 $(A$ (ナ
ノアンペア))，照射面橫（S）から計算可能 で，照射時間 $(t)$ を变化させるか，もしく はスリット（アテネータ）を入れることで 桁数コントロールが容易になされる。

Fluence (ions $/ \mathrm{cm}^{2}$ )

$$
=\frac{A \times 10^{-9}}{N \times 1.6 \times 10^{-19}} \cdot \frac{t}{S}
$$

本検討では，照射面䅡（S）を常に $3 \times$ $3 \mathrm{~cm}^{2}$ とした。 また，イオンが高分子膜に与 える影響の度合いはイオンの種類と高分子 膜の種類により变化する. Fig. 2 は, ジエチ レングリコール・ビス・アリルカーボネート 膜を使って算出されたブラッグカーブを示 す，横檕は重イオンが侵入した深さを表し， 縦軸は 1 イオン当りの膜へのエネルギー供 与を示している。縦軸の值が高いほど膜に 与えるエネルギーは大きい。例えば ${ }^{129} \mathrm{Xe}^{23+}$ (450MeV) の場合, 照射されたXeイオンは膜に衝突 直後に高いエネルギーを与えるが，40 $\mu \mathrm{m}$ 侵入した ところで急速に弱まり消滅してしまう特性を持つ。 この図から明らかなように，照射するイオンやエネ ルギーの違いにより膜内部に付与されるエネルギー やイオンの到達する距棐が買なることが分かる。 ま た，同じ照射イオンでも，その運動エネルギー（電 子ボルト：MeV）が異なれば膜へのイオンの侵入深 度が異なることも示している．各々の重イオンビー ムが高分子膜に照射された場合のエネルギー付与領 域は，Fig. 3に示したように重イオンが直接通過した コア領域と，重イオンが物質（ポリマー）に衝突し て弾き飛ばされた 2 次電子が及ほすすぺナンブラと呼ば れる領域に分けることが出来る。これらの領域サイ ズを特定するために各国で研究が行われているが， 重イオン照射によって誘起された槥造变化領域は不 明瞭な部分が多く，化学反応メカニズムさえもまだ 十分に明らかにされていない。

\section{3. 膜棈造变化}

重イオン照射による高分子膜内の㭗造変化検討に は, 結晶化度 $40 \%$, 膜厚 $38 \mu \mathrm{m}$ の PET (ポリエチレ ンテレフタレート）膜を用いた。照射重イオン種を 固定し，照射フルエンスを $3 \times 10^{3} \sim 3 \times 10^{9}$ ions $/ \mathrm{cm}^{2}$ と变化させて重イオン照射の誘発する現象を静 的㧍よび動的キャラクタリゼーションから考察した。 Table 1のサンプル名（Membrane）に扔ける右の数 字は乘数である（たと元ば，Xe-7 $=3 \times 10^{7}$ ions 


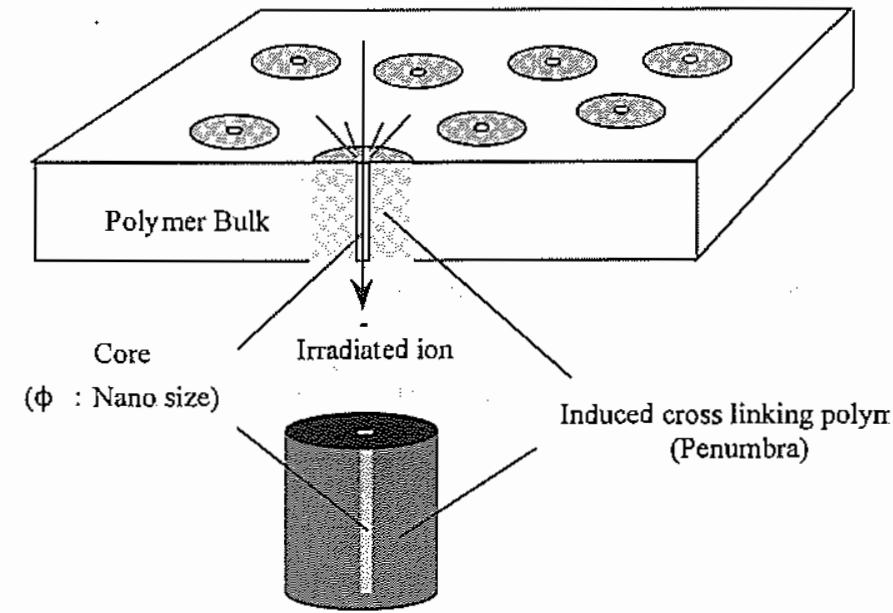

Fig. 3 Schematic representation of the structure change induced by heavy ion irradiation.

Table 1 The dynamic characterizations by DMA-7e. Unit of $T \tan \delta^{\circ}:{ }^{\circ} \mathrm{C}$

\begin{tabular}{lccc}
\hline Membrane & fluence $\left(\right.$ ions $\left./ \mathrm{cm}^{2}\right)$ & $\tan \delta$ & $\mathrm{T}_{\tan \delta}$ \\
\hline PET & - & 0.098 & 104.41 \\
$\mathrm{Xe}-3$ & $3.0 \times 10^{3}$ & 0.141 & 109.56 \\
$\mathrm{Xe}-6$ & $3.0 \times 10^{6}$ & 0.145 & 105.69 \\
$\mathrm{Xe}-7$ & $3.0 \times 10^{7}$ & 0.150 & 105.83 \\
$\mathrm{Xe}-8$ & $3.0 \times 10^{8}$ & 0.155 & 105.27 \\
$\mathrm{Xe}-9$ & $3.0 \times 10^{9}$ & 0.146 & 105.25 \\
\hline
\end{tabular}

$\left./ \mathrm{cm}^{2}\right)$. 重イオン照射によるわずかな分子棈造変化を 詳細に観察するため顕微 FT-IRを用いた。その結果, 原子核の衝突による膜内でのアモルファス履の增加 とPETのエステル結合部の切断によるエステル伸縮 振動の増加が確認された。このFT-IR測定結果におい ては，他の研究者も同様な考察を示している4 5 . FT-IR測定で示唆されたアモルファス畨の増加は示差 走查䇾量計（DSC）测定による融解熱の滅少結果加 らも支持されている ${ }^{6)}$ ．さらに，動的測定として引張

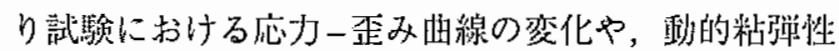
测定を利用することにより，膜强度の変化を考察し た。标的測定加求められる $\tan \delta$ は損失正姜 (loss tangent）とも言われる減裹值で，そのピーク埧度は 哨的測定から得られたTgに近い。一般に減衰は主と して無定形相に起因する。Table 1に示したようにXe イオンを照射した償における $\tan \delta$ 值の向上から，照 射レベルに依存したエネルギー損失が確認できる。 また, $\tan \delta$ ピーク温度も高湿侧にシフトしており，

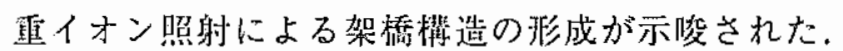
また, Fig. 4の引張り試験における応力一歪み明線の

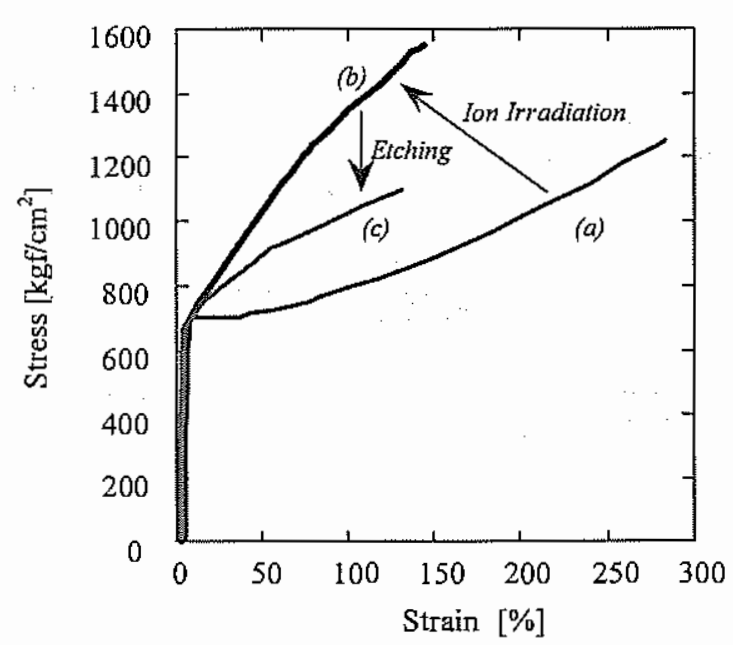

Fig. 4 Typical stress-strain curves for (a) PET, (b) Xe ion irradiated PET $\left(3.0 \times 10^{9}\right.$ ions $\left./ \mathrm{cm}^{2}\right)$ and (c) Ion-irradiated PET $\left(3.0 \times 10^{9}\right.$ ions $\left./ \mathrm{cm}^{2}\right)$ followed by an etching with $6 \mathrm{M}-\mathrm{NaOH}$ for $180 \mathrm{~s}$.

Polymer Journal, Vol.36, No.1（2004）より郡截

変化から，重イオン照射により PET膜は，より硬く 脆い材料へと変化したことが判明した。高いエネル ギーを持った重イオンが膜内を通過し，ポリマー鎖 との衔突によって弾き飛ばされた 2 次電子がペナンブ ラ領域として架橋層を泟成したものと推察できる. DSC 測定に扔いても僅かなガラス忶移温度変化や工 ンタルピー変化によって重イオン照射による架橋楼 造形成を数值的に捉えており，ペナンブラ領域は架 橋啳からなっている事を明示するとともにFig. 3 に描 いたような架橋䙓で围まれたナノサイズポアを持つ ポリマーチューブの形成を報告した6).

\section{4. 重イオン照射膜の気体透過性}

重イオン照射膜の気体透過性検討には，透過测定 の便宜性を考感し，膜厚 $12 \mu \mathrm{m}$ の PET膜（結晶化淁 40\%）を用いた。重イオンの種類またはブルエンスを

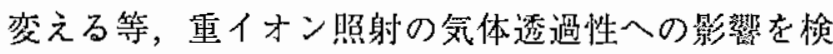
討した ${ }^{3)}$ 。重イオンは ${ }^{129} \mathrm{Xe}^{23+}(450 \mathrm{MeV}),{ }^{15} \mathrm{~N}^{3+}$ $(56 \mathrm{MeV}),{ }^{20} \mathrm{Ne}^{4+}(75 \mathrm{MeV}),{ }^{40} \mathrm{Ar}^{8+}(150 \mathrm{MeV})$, ${ }^{34} \mathrm{Kr}^{17+}(150 \mathrm{MeV})$ を使用した．高分子膜への影響力 は前述したように重イオン種とそのエネルギーの強 さに依存して暴なっている，重イオン照射による密 度やX線回折測定によって求められた面間關值 $\mathrm{d}$ spacingの変化は無く, 装面の接促解も変化はほとん どみられなかった. Fig. 2に示した重イオンの特性か ら，照射重イオンは膜厚 $12 \mu \mathrm{m}$ のPET膜を賁通して いるはずであるが，Arイオン照射膜においてはPET 膜と同椂，気体分子はその濃度勾配の駱動力の下で 


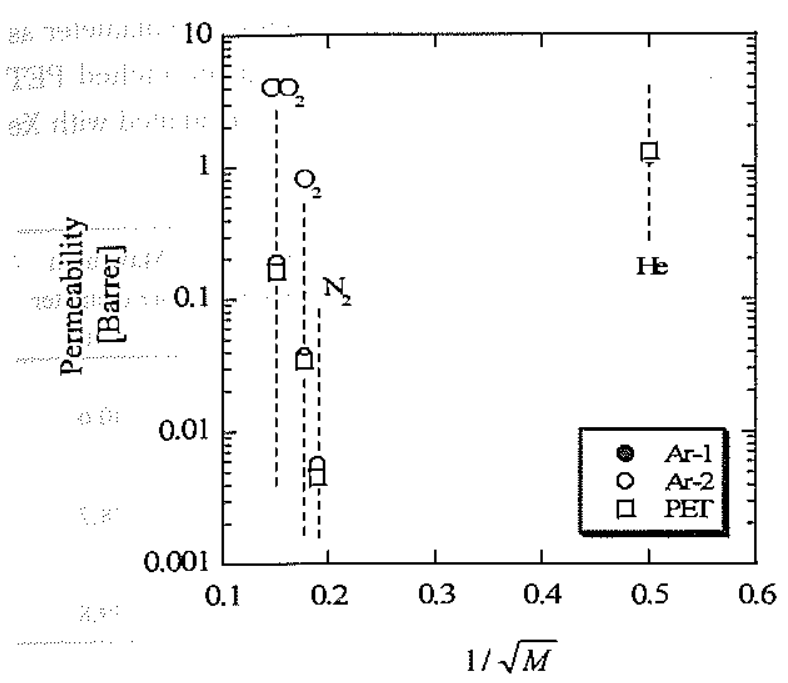

Fig. 5 Relationship between the permeability rate and the reciprocal of the square root of the molecular weight of gases at $303 \mathrm{~K}$.

Ar-1: ${ }^{40} \mathrm{~A} r^{8+}(150 \mathrm{MeV})$ was irradiated, Fluence is $8.6 \times 10^{10}$ ions $/ \mathrm{cm}^{2}$

Ar-2 : ${ }^{40} \mathrm{~A} r^{8+}(150 \mathrm{MeV})$ was irradiated, Fluence is

$1.3 \times 10^{11}$ ions $/ \mathrm{cm}^{2}$

PET: Pure Poly (ethylene terephthalate) membrane

溶解搪散機筝で透過している (Fig. 5)。重イオン照 射により一庭点分子鎖は切断されるが，ダメージの

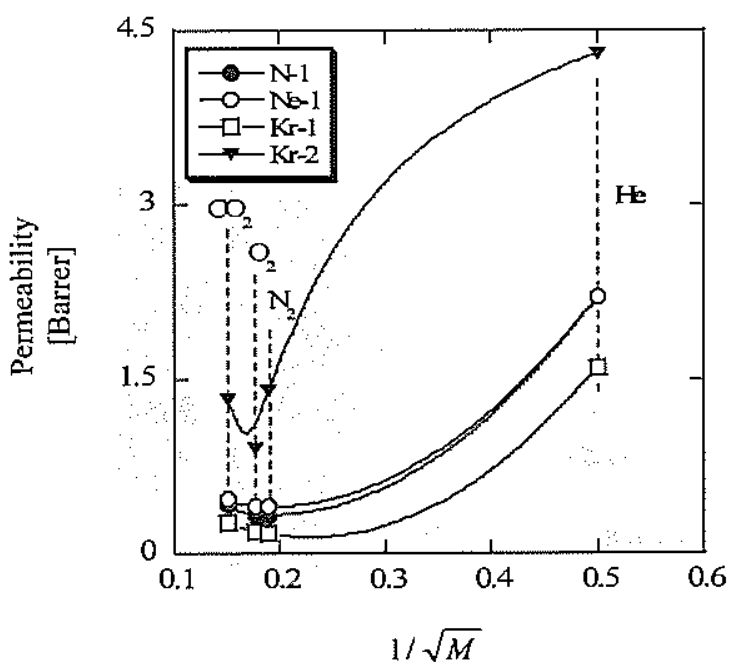

Fig. 6 Relationship between the permeability rate and the reciprocal of the square root of the molecular weight of gases at $303 \mathrm{~K}$.

$\mathrm{N}-1:{ }^{15} \mathrm{~N}^{3+}(56 \mathrm{MeV})$ was irradiated, Fluence is 5.7 $\times 10^{10}$ ions $/ \mathrm{cm}^{2}$

$\mathrm{Ne}-1:{ }^{20} \mathrm{Ne}^{4+}(75 \mathrm{MeV})$ was irradiated, Fluence is $8.7 \times 10^{10}$ ions $/ \mathrm{cm}^{2}$

$\mathrm{Kr}-1:{ }^{84} \mathrm{Kr}^{17+}(322 \mathrm{MeV})$ was irradiated, Fluence is $6.0 \times 10^{10}$ ions $/ \mathrm{cm}^{2}$

$\mathrm{Kr}-2:{ }^{84} \mathrm{Kr}^{-17+}(150 \mathrm{MeV})$ was irradiated, Fluence is $1.0 \times 10^{11}$ ions $/ \mathrm{cm}^{2}$

弱さから再結合したものと考えられる。しかし，重 イオン種の変化やフルエンスの增加により, 溶解拡 散による気体透過の依存度が減少しはじめ，フルエ ンスを $10^{11}$ ions $/ \mathrm{cm}^{2}$ とした $\mathrm{Kr}$ イオン照射膜（Kr-2） では，分子径のより大きな空素ガスの透過倸数が酸 隶のそれを上回る結果となった（Fig. 6).さららに， 高いエネルギーを持つXeイオン照射膜（Xe-2）と脰 フルエンスのNeイオン照射膜（Ne-2）に扔いて，気 体はその気体分子量の平方根に逆比例するクヌーセ ンフローを示して透過した。 また，高フルエンスの $\mathrm{N}$ イオン照射膜（N-2）は，非常に高い透過倸数を示 し，透過挙動はクヌーセンフロー同椂に気体分子量 の平方根の逆数に対して直線関係を示した（Fig. 7). これらの結果を踏まえ，イオンの種類やフルエンス を変化させることで, 重イオン照射膜による気体の 透過は以下の三つの透過機桪に分類を れた。

(1) 重イオン照射により一度高分子鎖は切断（ラジカ ルを形成）されるが，ダメージの弱さから再結合 しているため, 気体は溶解拡散機㯕で透過する (Fig. 5).

(2) 重イオン照射によりいくつかの微細な貫通孔を形 成するものの，その絶対数が少なく，気体は溶解 


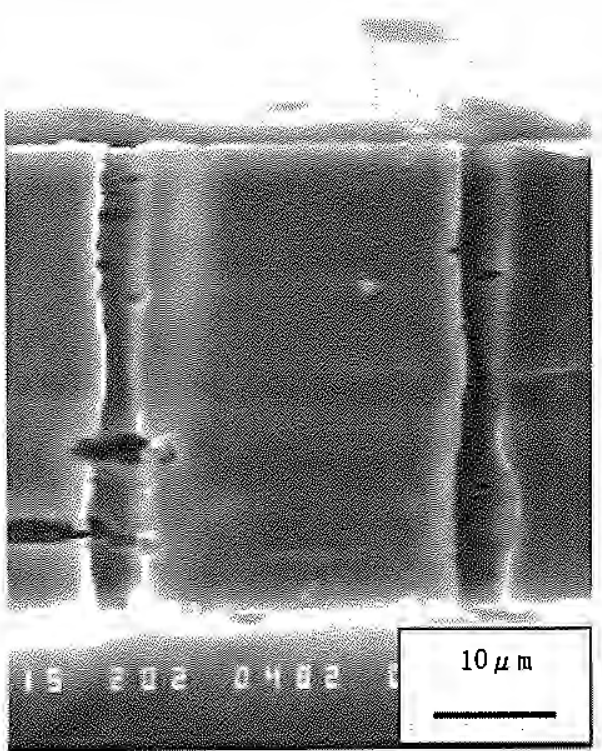

Fig. 8 A cross-sectional view of PET film which was obtained by etching in aqueous $6 \mathrm{M}-\mathrm{NaOH}$ solution at $60^{\circ} \mathrm{C}$ for one hour after $\mathrm{Xe}$ ion irradiation. These samples were cut by microtome.

拡散とクヌーセンフローの混合機榄で透過する (Fig. 6).

(3) 重イオン照射により貫通孔が形成され，気体はク ヌーセンフロー的な挙钦を示して透過する

(Fig. 7).

上記(3)を満たすのに適した重イオンは ${ }^{129} \mathrm{Xe}^{23+}$ $(450 \mathrm{MeV}),{ }^{15} \mathrm{~N}^{3+}(56 \mathrm{MeV}),{ }^{20} \mathrm{Ne}^{4+}(75 \mathrm{MeV})$ であっ た。なかでも ${ }^{129} \mathrm{Xe}^{23+}$ 照射はより小さいフルエンスで クヌーセンフローを示す膜の調斐を可能にしたが， フルエンスは $10^{10} \mathrm{ions} / \mathrm{cm}^{2}$ と比較的高密度にする必 琶があった。また $10^{13} \mathrm{ions} / \mathrm{cm}^{2}$ 以上の高いフルエン スでの重イオン照射膜は照射領域が褐色に毞け，も ろくなったことから，膜への負担も考慰しなければ ならないことが非明しだ．

\section{5. エッチングによる孔径コントロール}

エッチング処理による孔径制御と気体透過性制御 の倹討には, 棑造变化検討と同㥞, 膜厚 $38 \mu \mathrm{m}$ の PET膜（結晶化度 40\%）を利用した7．この検討で， $38 \mu \mathrm{m}$ のPET膜を使用したのは，膜断面写真の测定 とエッチング操作による膜の少化を考虙したためで ある．重イオン照射に上る多孔膜の特徴は，孔密度 を自由にコントロールでき，Fig. 8に示したSEM写 真のように買通孔が全て $Z$ 俥方向に韭直であるとい うことである。重イオン照射を利用した孔径制御の 検討は他の研究械関でも行われており，その孔径の
Table 2 Pore diameter distribution and maximum pore diameter as a function of etching time or etchant in the etched PET membranes. The PET membranes were irradiated with Xe ion $\left(3.0 \times 10^{9}\right.$ ions $\left./ \mathrm{cm}^{2}\right)$

\begin{tabular}{ccccc}
\hline Etchant & $\begin{array}{c}\text { Etch-temp. } \\
(\mathrm{C} C)\end{array}$ & Etch-time & $\begin{array}{c}\text { Pore diameter } \\
\text { distribution } \\
(\mathrm{nm})\end{array}$ & $\begin{array}{c}\text { Maximum } \\
\text { pore diameter } \\
(\mathrm{nm})\end{array}$ \\
\hline $6 \mathrm{~N}-\mathrm{NaOH}$ & 60 & $120 \mathrm{sec}$ & $\begin{array}{c}1.5-3.8 \\
6.7-9.2\end{array}$ & 40.6 \\
$6 \mathrm{~N}-\mathrm{NaOH}$ & 60 & $135 \mathrm{sec}$ & $\begin{array}{c}3.8-5.0 \\
22.6-38.2\end{array}$ & 38.2 \\
& & & & \\
$1 \mathrm{~N}-\mathrm{NaOH}$ & 60 & $28 \mathrm{~min}$ & $23.9-39.8$ & 39.8 \\
\hline
\end{tabular}

確認方法も様々である ${ }^{8)}$. また日本原子力砳究所の吉 田らは，環境応答性膜に重イオン照射しエッチング 処理をすることで多孔膜を作製し，温度変化などで 孔の開閉をコントロールできるインテリジェント多 孔膜を報告している1 2,9)。ここでは前章で述べた膜 への負担などを考虑し，フルエンスを $10^{9}$ ions $/ \mathrm{cm}^{2} に$ 設定してエッチングによる孔径コントロールを目的 とした実験を行った。エッチング処理は $1 \mathrm{~N}$ と $6 \mathrm{~N}$ の 水酸化ナトリウム水溶液を用いた。エッチング処理 によって貫通孔が容易に形成され，屈折率の変化に よって膜が白化現像を起こす。この白色化を貫通孔 形成の目安とし，水溶液温度を $60^{\circ} \mathrm{C} に$ 保方，处理時 間をコントロールした，孔径分布はバブルポイント 法に基づく細孔径評仙装琪ナノパームポロメータ (Nano-permporometer;西華産業(俳) を使用して測定 し，その結果を Table 2 に示した，高徽度の水酸化ナ トリウム溶淮では，短時間で貫通孔を形成し，その

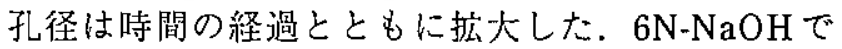
$120 \mathrm{sec}$ エッチングした重イオン照射膜の最大孔径 (40.6nm) は，测定䇛围外にあることから照射部分の オーバーラップによって形成された絶対数の少ない 孔と推测する，短洔間の鬲瀑度処理のため, Table 2 に示したデータには孔径分布にばらつきが見られる が，適切な水溶液潈度と封間, 水温のコントロール により，より䊑度の高い制御が出来るものと考えて いる。ささらに，Fig. 9に示されるようにエッチング処 理時間を延長させることで，その膜の気体透過挙動 はPET償の挙動（Fig. 9：文）加らクヌーセンフロー の挙政へと变化させ，気体透過係数を制御可能とし ている（1N-28sec, 6N-135min, 6N-120sec）。また， Fig. 3 に示したように，エッチングによる膜の強度は 未处理 PETに比べ㒖かに脆弱化し，伸び率に至って は半隇する絬果となっていることから，改良梌討の 必要性も残している。 


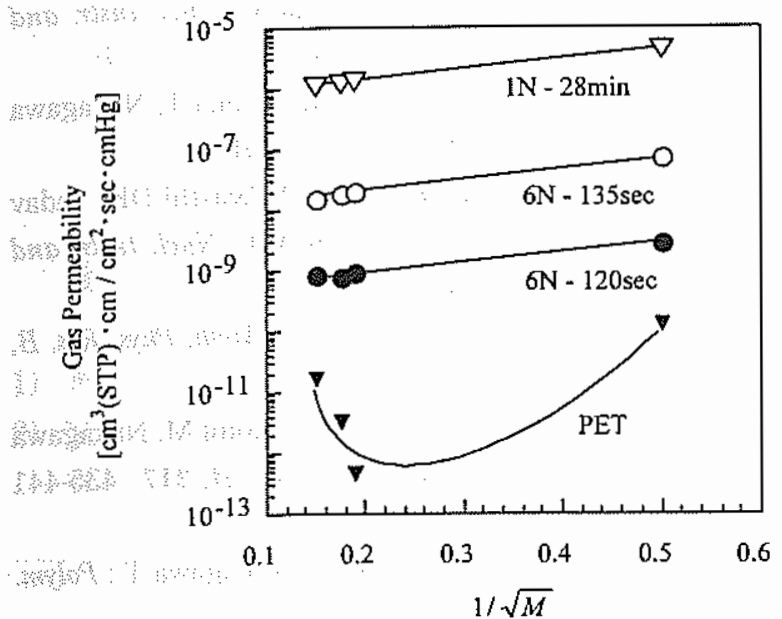

Fig. 9 Relationship between the gas permeability and the reciprocal of the square root of gaseous molecular weight at $303 \mathrm{~K}$

Polymer Joumal, Vol.36, No.1（2004）より記截

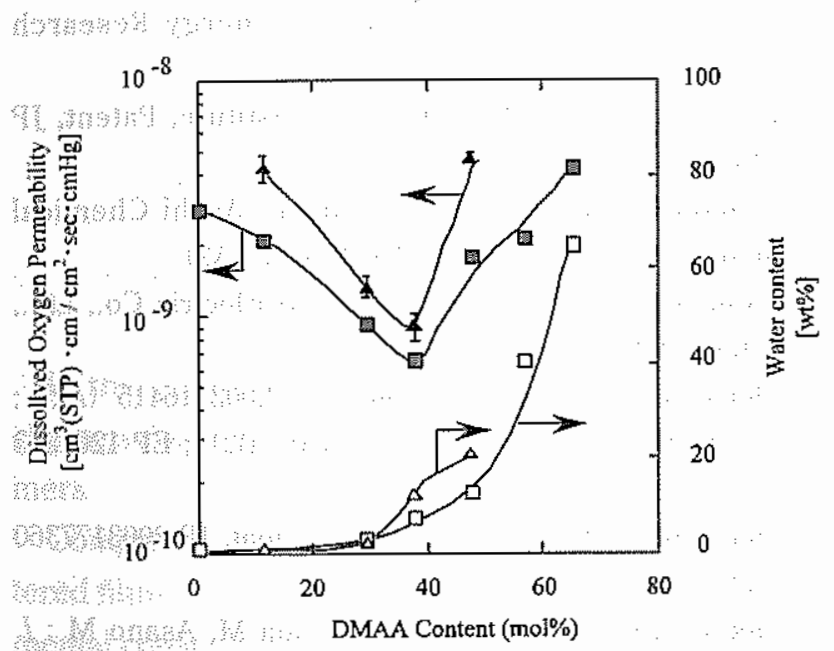

-

$\rightarrow$ Xe ion irradiated Poly(TMS-eo-DMAA)

$\rightarrow-$ Poly(TMS-co-DMAA) series (water content)

$\neg-$ Xe ion inadiated Poly(TMS-co-DMAA) (water content)

Fig. 11 Effect of Xe ion irradiation on the water content and the dissolved oxygen permeability coefficient of Poly (TMS-co-DMAA) membranes at $35^{\circ} \mathrm{C}$.

\section{6. 含水膜への応用}

重イオン照射の親水性高分子材料への応用を記述 ウる:コンタクトレンズの改翼に $\gamma$ 線や電子線など の放射線を利用した研究は数多くある10-15). 本章で はソフトコンタクトレンズ材料としても利用されて

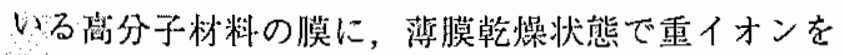

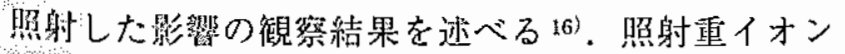

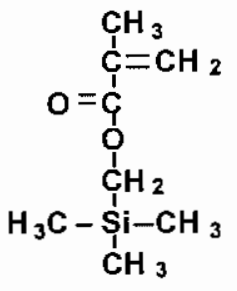

TMS<smiles>C=CC(=O)N(C)C</smiles>

DMAA
Copolymer<smiles></smiles>

Poly(TMS-co-DMAA)

Fig. 10 Structural formulae of Trimethylsilylmethyl methacrylate (TMS), N,N-dimethyl acrylamide (DMAA) and their copolymer, Poly (TMS-coDMAA).

は $450 \mathrm{MeV}$ の ${ }^{129} \mathrm{Xe}^{23+}$ ，フルエンスは $10^{10}$ ions $/ \mathrm{cm}^{2}$ と した：用いた离分子材料は，漞水性モノマーのジメ チルアクリルアミド（DMAA）と酸素拡政性が高く シリコンを含有した疎水性モノマーのトリメチルシ リルメチルメタクリレート (TMS) の共箠合体で, その辈造式はFig. 10に示した．膜厚はすべて $50 \mu \mathrm{m}$ に調製した。さらに共重合比率を变えることにより 含水率及び水溶存酸素透過性变化とその重イオン照

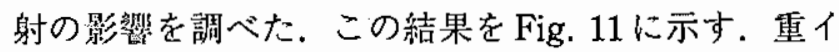
オン照射後は照射前と比べ含水乷が上昇しており， 親水性モノマ一の比率が高い共重合体ほど重イオン 照射後の含水率上䒜は顕著になった，赤外線吸取ス ペクトル測定から重イオン照射による水酸基付与が 確認されており，含水率の增加は水酸基の堌加に起 因した。この水酸基の付与は親水性基を有する膜内 德境（大気から水蒸気を取り込みやすい環境）が影 留しているものと考えられ，高エネルギーの重イ才 ン照射による分子鍞切断によって発生したラジカル が酸化されることで水酸基が生じたものと考察して いる。また，親水性モノマー比率のより离い共重合 体膜は，照射前の良溶媒に不溶となることから重イ オン照射によって架橋反応が進行していることも碓 認された。重イオン照射前後でGPC測定が可能であ った 10 mol\%DMAAの共重合体膜Poly（TMS-coDMAA) は数平均分子最が $6 \times 10^{5}$ 加ら $7 \times 10^{4}$, 分 政度が 19 から 58 となり，重イオン照射による低分子 
量化と分散度拡大が重イオン照射による分子鎖切断 を証明した。重イオンの照射によって架橋蓝造を形 成したにもかかわらず，重イオン照射前に比べ1オ一 ダー程度高い溶存酸素透過係数を示しており，この 検討から架橋による膜の補強效果と含水率の上昇に よる溶存酸素透過性向上を示す興味深い結果を得た。

\section{7. おわりに}

本総説は䯩分子膜への重イオン照射の影煭をその 気体透過性を中心にまとめたものである，実験に用 いた膜が限定されているため，他の高分子膜では影 響が異なることもあるであるう。しかしながら，重 イオン照射は未来の改質技術としても注目されてき ており，2000年以降は重イオン照射による高分子改 質研究が普及し，その関連諭文数もここ数年で增加 傾向にある。また，本説でも示したように，ナノサ イズの貫通孔を持つ円筒状架橋ポリマーを作製でき る見込みもあり，電気伝導性ポリマーを使用するこ とでカーボンナノチューブに次ぐ次期未来ナノ材料 の創裝も夢ではない。

\section{謝辞}

重イオン照射検討の遂行に当たり, 日本原子力研 究所の吉田絴博士, 浅野雅春博士に多大なるご助力, ご助言を頂きました。また, 明治大学の仲川䩻名誉 教授より多くのご助言を頂きましたことに，この場 を借りて謝意を表します。

\section{文献}

1）浅野雅春，吉田、勝，大道英薣，長岡簿安，久保田仁， 片貝良一, Reber N, Spohr R: 放射線，22 61-70 (1996)

2) Yoshida M, Nagaoka N, Asano M, Omichi H, Kubota $H$,
Ogura K, Vetter R, Spohr R, Katakai R : Nucl. Instr. and Meth. Phys. Res. B, 122 39-44 (1997)

3) Takahashi S, Yoshida M, Asano M, Tanaka T, Nakagawa T: J. Appl. Polym. Sci., 82 206-216 (2001)

4) Biswas A, Lotha S, Fink D, Singh JP, Avasthi DK, Yadav BK, Bose SK, Khating DT, Avasthi AM : Nucl. Instr. and Meth. Phys. Res. B, 159 40-51 (1999)

5) Ciesla K, Starosta $\mathrm{W}$ : Nucl. Instr. and Meth. Phys. Res. B, $105 \quad$ 115-119 (1995)

6) Takahashi S, Yoshida M, Asano M, Notomi M, Nakagawa $\mathrm{T}$ : Nucl. Instr. and Meth. Phys. Res. B, 217 435-441 (2004)

7) Takahashi S, Yoshida M, Asano M, Nakagawa T: Polym. $J ., 36$ (1), 50-53 (2004)

8) Apel P, Schilz A, Spohr R, Trautmann C, Vutsadakis V: Nucl. Instr. and Meth. Phys. Res. B, 146 468-474 (1998)

9) Yoshida M, Asano M, Safranji A, Omichi H, Vetter R, Spohr R, Vetter R, Katakai R : Macromolecules, 29 89878989 (1996)

10) Seed KK, Japan ; Japan Atomic Energy Research Institute, Patent, JP 04140711

11) Japan Atomic Energy Research Institute, Patent, JP 04358532 (A2)

12) Nippon Contact Lens, Inc., Japan ; Asahi Chemical Industry Co., Ltd., Patent, JP 03217815 (A2)

13) Menicon Co., Ltd., Japan ; Iwasaki Electric Co., Ltd., Patent, JP 07138392 (A2)

14) Menicon Co., Ltd., Japan, Patent, JP 2002116415 (A2) ; US 2002064597 (A1) ; US 6610350 (B2) ; EP 1201253 (A1)

15) Fuji Photo Film Co., Ltd., Japan, Patent, JP 2003177360 (A2)

16) Takahashi $S$, Nakagawa $T$, Yoshida $M$, Asano $M: J$. Membr. Sci., 206 165-177 (2002)

(Received 15 December 2003; Accepted 26 July 2004) 